\title{
The potential of forest reserves for augmenting the protected area network in Africa
}

\author{
Neil D. Burgess, Colby Loucks, Sue Stolton and Nigel Dudley
}

\begin{abstract}
The protected area network of Africa has grown from nothing to over 2 million $\mathrm{km}^{2}$ in the past 110 years. This network covers parts of all biomes and priority areas for biodiversity conservation but protected area gaps remain, as identified at the 5th World Parks Congress in 2003. Forest reserves, managed by Forest Departments, are typically excluded from global protected area lists, but in Africa they are found in 23 countries and cover at least $549,788 \mathrm{~km}^{2}$, adding $25 \%$ to the conservation estate. Forest reserves protect $5.3 \%$ $\left(2,027 \mathrm{~km}^{2}\right)$ of the dry forest habitats, $5 \%\left(165,285 \mathrm{~km}^{2}\right)$ of lowland and montane moist forests, $2.6 \%\left(364,354 \mathrm{~km}^{2}\right)$ of savannah woodlands, $1.8 \%\left(10,561 \mathrm{~km}^{2}\right)$ of flooded grasslands, and $1.65 \%\left(1,177 \mathrm{~km}^{2}\right)$ of mangroves. Forest reserves also protect parts of three conservation schemes: $6.5 \%\left(61,630 \mathrm{~km}^{2}\right)$ of BirdLife's Endemic Bird Areas, 3.4\% $\left(147,718 \mathrm{~km}^{2}\right)$ of Conservation
\end{abstract}

International's Hotpots and 3.4\% $\left(346,864 \mathrm{~km}^{2}\right)$ of WWF's Global 200 Ecoregions. Several of the global protected area gaps identified in Africa are also covered by forest reserves, in the Eastern Arc Mountains, Eastern African coastal forests, Kenyan Highlands, CameroonNigerian Mountains, West African Forests and mountain areas of Malawi, Zimbabwe, Mozambique and Zambia. Some African forest reserves have a legally defined role in biodiversity conservation and are strictly protected; they thus fit criteria for protected areas. Working with forest departments in individual countries may help develop a more comprehensive protected area network without creating additional new reserves.

Keywords Africa, biomes, Ecoregions, Endemic Bird Areas, forest reserves, Hotspots, protected area network.

\section{Introduction}

Protected areas, typically managed by government agencies, are one of the cornerstones of conservation efforts and arguably provide the best mechanism to preserve intact biodiversity values over the long-term across Africa and other continents. By the 5th World Parks Congress in 2003, $11.5 \%$ of terrestrial habitats were within protected areas (Chape et al., 2003). However, the coverage of biomes by these protected areas is uneven (Brooks et al., 2004) and in Africa there are a number of gaps in the protected area network for different species groups (de Klerk et al., 2004; Fjeldså et al., 2004; Rodrigues et al., 2004a,b; Burgess et al., 2005), and habitats (Brooks et al., 2004).

Neil D. Burgess ${ }^{\star}$ (Corresponding author) and Colby Loucks WWF Conservation Science Program, 1250 24th Street, NW, Washington, DC, USA. E-mail neil.burgess@wwfus.org

Sue Stolton and Nigel Dudley Equilibrium Consultants, 47 The Quays, Cumberland Road, Spike Island, Bristol, UK.

*Also at: Conservation and Management of the Eastern Arc Mountain Forests, Forestry and Beekeeping Division, P.O. Box 289, Morogoro, Tanzania, and Conservation Biology Group, Zoology Department, Cambridge University, Downing Street, CB2 3EJ, UK.

Received 7 October 2005. Revision requested 3 April 2006. Accepted 3 August 2006.
Since the 5th World Parks Congress, the Convention of Biological Diversity, international NGOs and various national governments have focused on how to complete a protected area network that best covers the distribution of biomes, habitats and species. Most of these initiatives are focused on those sites that have been given global recognition through their assignment to one of the six IUCN Protected Area Management Categories (IUCN et al., 1994). The Categories are defined as being managed mainly for: science (Ia) or wilderness protection $(\mathrm{Ib})$, ecosystem protection and recreation (II), conservation of specific natural features (III), conservation through management intervention (IV), landscape/seascape conservation or recreation (V), and the sustainable use of natural resources (VI).

Here we firstly look at the coverage of African biomes by protected areas (those reserves with an IUCN Category). Secondly, we assess how biome coverage is augmented by including the extensive network of forest reserves across Africa, which are managed for purposes ranging from sustainable timber harvesting to strict catchment protection. Thirdly, we look at the protected area coverage of Global 200 Ecoregions (Olson \& Dinerstein, 1998; Burgess et al., 2004a), Biodiversity Hotspots (Myers et al., 2000) and Endemic Bird Areas (Stattersfield et al., 1998) and assess how much additional habitat is conserved within forest reserves outside 
the official protected area network. Fourthly, we assess whether the existing network of forest reserves could help to close the gaps in the protected area network that were outlined at the 5th World Parks Congress.

Finally we outline a country by country process whereby nations could assess whether any of their forest reserves could be regarded internationally as a protected area and assigned an IUCN Protected Area Management Category. Such a process would allow these forest reserves to be recognized by UNEP-WCMC as protected areas in the World Database on Protected Areas (WDPA Consortium, 2005), which is the official source for the UN List of Protected Areas that is prepared every 4 years (Chape et al., 2003). Such a process would not only augment the coverage of the protected area network, but would also enhance the recognition of the role that Forestry Departments play in biodiversity conservation in Africa.

\section{Methods}

\section{Protected areas}

Protected areas in Africa are generally designated by government wildlife conservation agencies under categories such as National Park, Game Reserve or Game Controlled Area. These reserves are usually assigned Protected Area Management Categories according to the IUCN category system (IUCN et al., 1994), generally category II, III or IV. We extracted from the 2005 World Database on Protected Areas (WDPA Consortium, 2005) all reserved lands managed by protected area agencies that were been assigned an IUCN I-VI Category across mainland Africa from 1895 to 2004 . We excluded from the analysis all wildlife reserves that lacked an IUCN Category, reserve area or date of establishment. This excluded 459 sites, amounting to a total of $1,492,736 \mathrm{~km}^{2}$, from further analysis. The remaining 799 sites $\left(2,162,624 \mathrm{~km}^{2}\right.$ in total) that have full attribute data form our protected areas database (Table 1).

\section{Forest reserves}

African forest reserves are designated by government departments, typically Forestry Departments, and can have functions ranging from timber production to the strict protection of water sources. To develop the database of forest reserves we extracted all reserved lands from the 2005 World Database on Protected Areas that fall under the management of the various forestry agencies. We included the following forest reserve categories: Classified Forest, Forest Reserve, National Forest, State Forest and State Forest Reserve. Through this screening process we retained 3,804 forest reserves (out of c. 4,300 sites) that had sufficient information (Table 1); this is our forest reserves database. Only 93 (c. $3 \%$ of total) of these forest reserves have been assigned IUCN categories and are formally recognized as protected areas, 77 of which are in South Africa. The remainder (over 4,200 sites) have no IUCN category and are thus not recognized internationally as protected

Table 1 The nine continental African biomes and their total area, with the number, area and percentage of biome in protected areas assigned IUCN I-VI Protected Area Management Categories (IUCN et al., 1994) and in forest reserves, as derived from the World Database on Protected Areas (WDPA Consortium, 2005).

\begin{tabular}{|c|c|c|c|c|c|c|c|c|}
\hline \multirow[b]{2}{*}{ Biome $^{1}$} & \multirow[b]{2}{*}{$\begin{array}{l}\text { Short biome } \\
\text { name }\end{array}$} & \multirow[b]{2}{*}{$\begin{array}{l}\text { Total } \\
\text { area }\left(\mathrm{km}^{2}\right)\end{array}$} & \multicolumn{3}{|c|}{ Protected areas } & \multicolumn{3}{|c|}{ Forest reserves } \\
\hline & & & No. & $\begin{array}{l}\text { Area } \\
\left(\mathrm{km}^{2}\right)\end{array}$ & $\begin{array}{l}\% \text { of } \\
\text { biome }\end{array}$ & No. & $\begin{array}{l}\text { Area } \\
\left(\mathrm{km}^{2}\right)\end{array}$ & $\begin{array}{l}\% \text { of } \\
\text { biome }\end{array}$ \\
\hline Tropical \& subtropical grasslands & $\begin{array}{l}\text { Savannah } \\
\text { woodland }\end{array}$ & $13,981,400$ & 481 & $1,308,481$ & $9.36 \%$ & 2,617 & 364,354 & $2.61 \%$ \\
\hline Deserts \& xeric shrublands & Deserts & $9,626,100$ & 86 & 448,650 & $4.66 \%$ & 0 & 0 & $0.00 \%$ \\
\hline $\begin{array}{l}\text { Tropical \& subtropical moist broadleaf } \\
\text { forests }\end{array}$ & $\begin{array}{l}\text { Lowland \& } \\
\text { montane } \\
\text { rainforests }\end{array}$ & $3,246,500$ & 189 & 245,172 & $7.55 \%$ & 914 & 165,284 & $5.09 \%$ \\
\hline Montane grassland \& shrublands & Montane grassland & 867,400 & 121 & 43,896 & $5.06 \%$ & 121 & 6,385 & $0.74 \%$ \\
\hline Mediterranean forests, woodlands \& scrub & $\begin{array}{l}\text { Mediterranean } \\
\text { scrub }\end{array}$ & 846,300 & 51 & 10,985 & $1.30 \%$ & 0 & 0 & $0.00 \%$ \\
\hline Flooded grasslands & Flooded grasslands & 562,600 & 53 & 100,532 & $17.87 \%$ & 87 & 10,561 & $1.88 \%$ \\
\hline Mangroves & Mangroves & 71,500 & 2 & 42 & $0.06 \%$ & 20 & 1,177 & $1.65 \%$ \\
\hline Tropical \& subtropical dry broadleaf forests & Dry forests & 38,200 & 5 & 4,604 & $12.05 \%$ & 45 & 2,027 & $5.31 \%$ \\
\hline Temperate conifer forests & $\begin{array}{l}\text { Temperate conifer } \\
\text { forests }\end{array}$ & 23,100 & 6 & 261 & $1.13 \%$ & 0 & 0 & $0.00 \%$ \\
\hline Total & & $29,263,100$ & $799^{2}$ & $2,162,624$ & $7.39 \%$ & 3,804 & 549,788 & $1.88 \%$ \\
\hline
\end{tabular}

${ }^{1}$ From Olson et al. (2001)

${ }^{2}$ Number should not be summed, as a number of reserves cross different biomes, and their constituent areas are included in each biome. 
areas. The network of protected areas and forest reserves in Africa is mapped in Fig. 1.

\section{Analyses}

Nine continental African biomes were addressed by these analyses (Table 1). Coverage of biomes by protected areas was calculated by first overlaying the WDPA Consortium (2005) polygons for protected areas onto the biome maps developed by Olson et al. (2001) and applied to Africa by Burgess et al. (2004a). This determined the current area of each biome that is reserved and updates previous analyses (e.g. Dasmann, 1972). Thereafter the reserve establishment dates in the World Database on Protected Areas were used to assess changes in coverage over time. The same procedure was repeated for forest reserves. As the various biomes cover different areas we also calculated the percentage protection over time according to the area of the biome (Table 1).

In order to assess the degree to which biodiversity priorities in Africa are covered by protected areas, the World Database on Protected Areas polygons were overlaid onto Biodiversity Hotspots (Mittermeier et al., 2004), Global 200 Ecoregions (Olson \& Dinerstein, 1998; updated by Burgess et al., 2004a), and Endemic Bird Areas (Stattersfield et al., 1998). The same procedure was repeated for forest reserves, and the additional land area within the priority areas for biodiversity conservation was calculated. Although not a formal representation or irreplaceability analysis, this approach indicates the role that forest reserves play in biodiversity conservation.
The most comprehensive analyses of the species coverage by existing protected areas (Rodrigues et al., $2004 a, b)$ identified the following protected area gaps in Africa: western margins of the Upper Guinea forest (Sierra Leone and Liberia), Cameroon-Nigeria Highlands, Albertine Rift (Uganda, Democratic Republic of Congo, Burundi and Rwanda), Kenya Highlands, Eastern Arc Mountains (Tanzania and Kenya), eastern African coastal forests (Kenya and Tanzania), Ethiopian Highlands, Zimbabwe/Malawi/ Mozambique mountains, and coastal South Africa. To provide a simple assessment of how much additional land is covered by forest reserves in these regions, and thus the potential contribution of this reserve type to close some of the identified protected area gaps, we overlaid the World Database on Protected Areas polygons for protected areas and forest reserves onto these regions.

\section{Results}

The number of protected areas increased steadily across Africa throughout the early part of the 20th century, with the most rapid increase during the period 19701980 (Fig. 2). Those protected areas that have full attribute data in the World Database on Protected Areas covered 2,162,624 km² of the continent by 2004 . The four biomes with $>5 \%$ coverage in protected areas are savannah woodland, lowland and montane rainforests, flooded grasslands, and montane grasslands (Table 1). For the other five biomes (Mediterranean scrub, deserts, mangroves, dry forests, and temperate conifer forests) $<5 \%$ of their area are found within

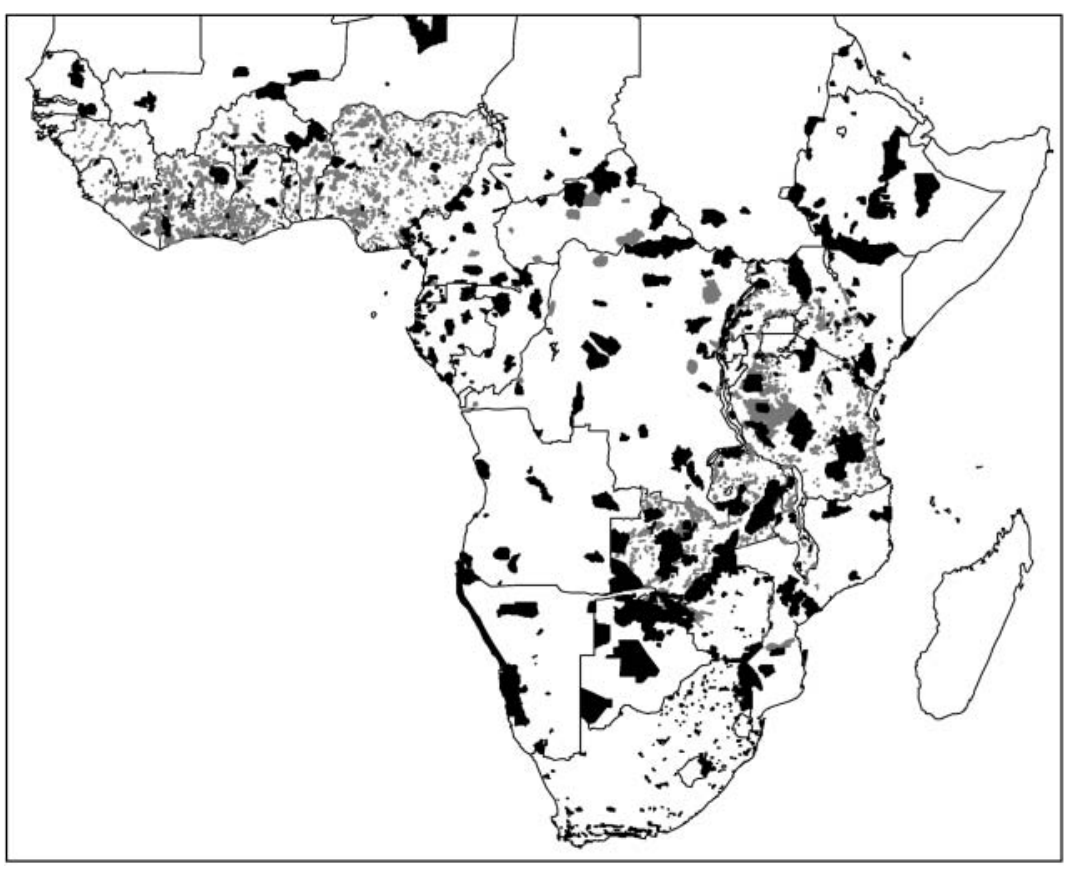

Fig. 1 Spatial distribution of the network of protected areas (black) and forest reserves (grey) in continental Africa south of the Sahara, derived from the data in the 2005 World Database on Protected Areas (WDPA Consortium, 2005). 


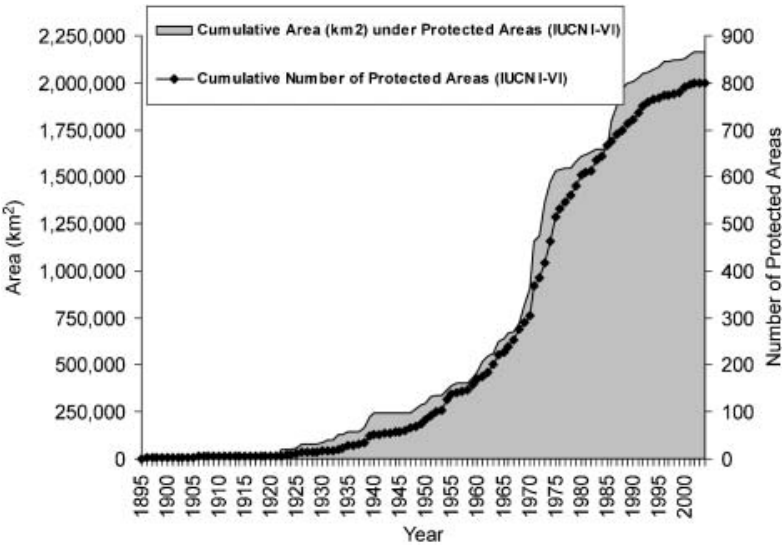

Fig. 2 Growth in protected area network of continental Africa (IUCN I-VI Protected Area Categories with full attribute data) between 1895 and 2004, based on the World Database on Protected Areas (WPDA Consortium, 2005). Grey shading and left axis shows total area protected. Black triangles and right axis shows total number of protected areas.

protected areas (Table 1). Many protected areas were declared in the savannah woodland biome in the 20th century, up until the end of the 1970s (Fig. 3). Since that time fewer savannah woodland habitats have been reserved and attention shifted in the 1980s to the reservation of other biomes with poor protected area coverage such as lowland and montane rainforests, Mediterranean scrub, flooded grasslands and deserts (Fig. 3).

Those forest reserves that have full attribute data in the World Database on Protected Areas covered $549,788 \mathrm{~km}^{2}$ in 2004 . This is an additional $25 \%$ of reserved land that is not officially recognized as protected area by UNEP-WCMC and IUCN (Table 1). The history of forest reserve creation mirrors that of protected areas, but with the peak years of reservation in Tanzania (as an example) being 1950-1970 (Fig. 4). The network of forest reserves increases the reserved area of a number of biomes, especially savannah woodland, lowland and montane rainforests, flooded grasslands, dry forest and mangroves (Fig. 5). Forest reserves also add significantly to the reserved area in those parts of Africa with the highest importance for biodiversity conservation (Table 2).

Almost all the protected area gaps identified in Africa (Rodrigues et al., 2004a,b) have significant coverage by forest reserves. For example, of the $c .23,000 \mathrm{~km}^{2}$ Eastern Arc Mountains of Tanzania and Kenya, globally outstanding for endemism (Lovett \& Wasser, 1993; Myers et al., 2000; Newmark, 2002; Burgess et al., 2004c), c. $1,900 \mathrm{~km}^{2}$ are within National Parks with an IUCN Protected Area Management Category and a further $3,300 \mathrm{~km}^{2}$ are within forest reserves (EAMCEF, 2006). Forest reserves also provide the majority of the protection to habitats within the globally important lowland coastal forests of eastern Africa, with $2,400 \mathrm{~km}^{2}$ in forest reserves and $440 \mathrm{~km}^{2}$ in all other reserve categories combined (Burgess \& Clarke, 2000; Burgess et al., 2004b). Important networks of forest reserves are also found in the Southern Rift Mountains of Tanzania and Malawi (Burgess et al., 2004c), Upper Guinea forests of West Africa (Hawthorne \& Abu-Jaum, 1995), highlands of Kenya (Wass, 1995), and lowland and mountain portions of Uganda (Howard, 1991; Howard et al., 2000).

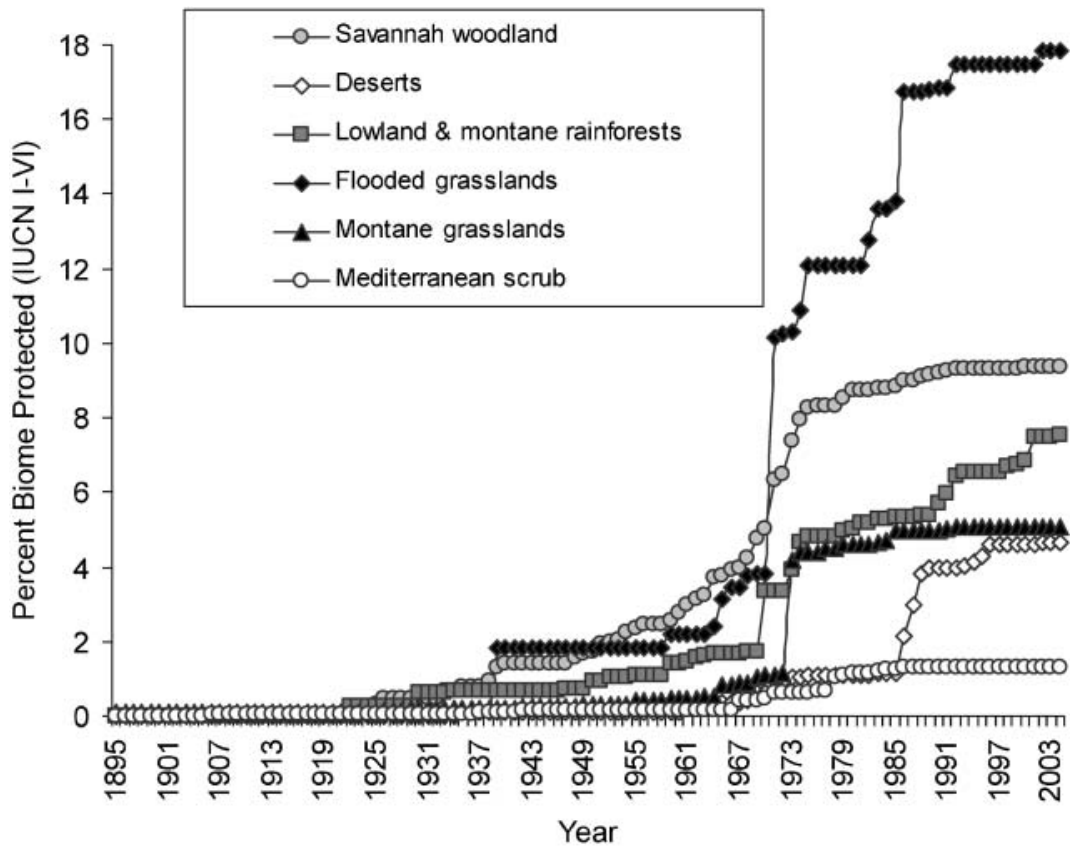

Fig. 3 Annual percentage increase in protected area (IUCN I-VI Protected Area Categories) coverage of the six largest biomes (Table 1) in continental Africa from 1895 to 2004, based on the World Database of Protected Areas (WDPA Consortium, 2005). 


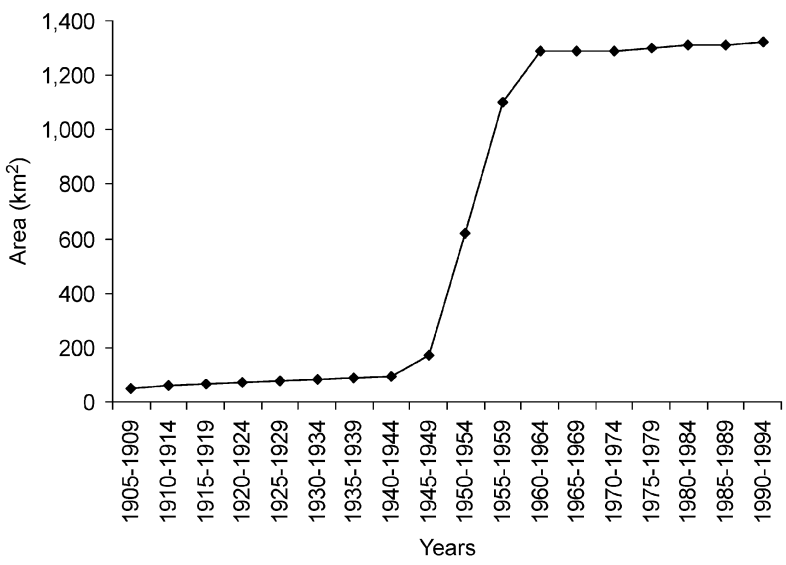

Fig. 4 Development of the Tanzanian Forest Reserve network from 1905 to 1998 in Morogoro Region. Data taken from the records of the Forestry and Beekeeping Division, Tanzania. More than 300 forest reserves in Tanzania, covering $26,600 \mathrm{~km}^{2}$, have no year of declaration and hence cannot be plotted. Many of these are old reserves, some dating back to the 1890s and were declared by the German colonial administration.

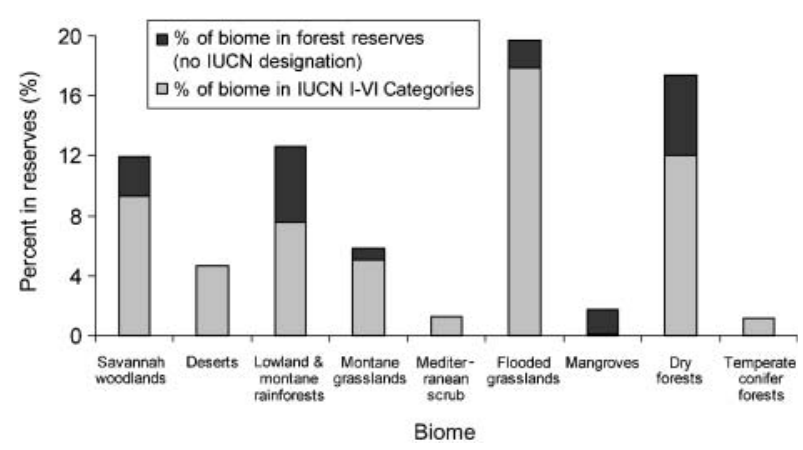

Fig. 5 Additional protection of the six largest biomes on continental Africa by existing forest reserves, using data from the 2005 WDPA (WDPA Consortium, 2005).

\section{Discussion}

Although there has been an increase in the protected area estate of Africa over time some biomes remain poorly covered. In many African countries there are important networks of forest reserves managed by Forestry Departments, and these augment the protected area estate in terms of area coverage, particularly within forest biomes. These networks of forest reserves also enhance the protected area coverage of critical regions for biodiversity conservation and close some of the gaps in the protected area network.

\section{Can forest reserves be protected areas?}

This is a controversial issue, with some types of forest reserves being heavily protected and regarded as de facto protected areas (Stolton \& Dudley, in press) whereas others are managed solely for maximum timber production, sometimes as plantations of exotic species. For example, in Malawi plantations covered $840.5 \mathrm{~km}^{2}$ of the country's forest reserves in the late 1980s, c. $10 \%$ of the total (Millington \& Townsend, 1989). The basis for deciding if a given forest reserve could be recognized as a protected area is found in the official definition of a protected area and in the law of the country concerned. The IUCN definition of a protected area is 'an area of land and/or sea especially dedicated to the protection and maintenance of biological diversity, and of natural and associated cultural resources, and managed through legal or other effective means' (IUCN et al., 1994). If the laws of a country do not allow forest reserves to have a role in biodiversity conservation then there is no legal basis for them to be recognized as protected areas. However, Tanzania, Kenya and Uganda (and perhaps other countries for which we have not reviewed their national laws) have forest policies and laws that recognize the contribution that forest reserves make to biodiversity conservation, and Tanzania and Uganda both have strictly protected forest reserve classes that are managed for the maintenance of the forest habitat, its biological values and the supply of ecosystem services (e.g. water). In African countries with the relevant policies and laws we believe that forest reserves have the potential to be classified as protected areas.

\section{Can forest reserves be coded as IUCN Protected Area Categories?}

In countries where policies and laws could allow forest reserves to be regarded as protected areas it is also

Table 2 Coverage by IUCN Category Protected Areas and forest reserves of three conservation schemes: Biodiversity Hotspots (Conservation International; Mittermeier et al., 2004), Global 200 Ecoregions (WWF; Burgess et al., 2004a), and Endemic Bird Areas (BirdLife; Stattersfield et al., 1998).

\begin{tabular}{llllll}
\hline & $\begin{array}{l}\text { Area of scheme } \\
\text { in continental } \\
\text { Africa }\left(\mathrm{km}^{2}\right)\end{array}$ & $\begin{array}{l}\text { Area }(\%) \text { of scheme } \\
\text { in IUCN Categories } \\
\text { I-VI }\left(\mathrm{km}^{2}\right)\end{array}$ & $\begin{array}{l}\text { Forest reserves } \\
\text { with IUCN } \\
\text { Category }\left(\mathrm{km}^{2}\right)\end{array}$ & $\begin{array}{l}\text { Forest reserves } \\
\text { without IUCN } \\
\text { Category }\left(\mathrm{km}^{2}\right)\end{array}$ & $\begin{array}{l}\text { \% of scheme in forest } \\
\text { reserves with no } \\
\text { IUCN Category }(\%)\end{array}$ \\
\hline Global 200 Ecoregions & $10,239,484$ & $406,973(3.97)$ & 8,197 & 346,864 & 3.39 \\
Hotspots & $4,369,470$ & $315,737(7.23)$ & 9,945 & 147,718 & 3.38 \\
Endemic Bird Areas & 939,046 & $123,763(13.18)$ & 7,526 & 61,630 & 6.56 \\
\hline
\end{tabular}


appropriate to consider whether they can be coded as IUCN Protected Area Management Categories (IUCN et al., 1994). During a meeting of Eastern and Southern African protected area agencies and Forestry Departments in Nairobi in 2005 it was agreed that some existing forest reserves have the potential to be included within the protected area network (Stolton \& Dudley, in press). It was recommended that in each country where the potential exists, an analysis of the network of reserves should be undertaken. The objectives of such an assessment would be to determine which of the forest reserves in a country are of the highest conservation priority (e.g. Howard et al., 2000), to review the current management regimes to determine if they are favourable for conserving biological values, and to initiate a process to try and either designate the highest priority areas for conservation or put in place management plans that allow the features of highest conservation importance to be maintained.

At the same meeting it was agreed that once nations decide that at least some of their forest reserves could also be recognized as protected areas, a useful first step would be to categorize the reserves in four broad groups: (1) already de facto protected areas, (2) almost equivalent to protected areas, (3) far from being equivalent to protected areas, (4) never going to be protected areas (e.g. plantations). This would make clear which of the existing forest reserves in a country have a chance of being incorporated into the protected area network. The 2005 meeting in Nairobi developed a flow chart to assist agencies in assigning IUCN Protected Area Management Categories to their networks of reserves (Fig. 6; Stolton \& Dudley, in press). This approach should be applicable to all types of reserves, whether they are national parks, forest reserves, or even community-managed areas.

\section{Will allocating an IUCN Category improve management?}

The allocation of an IUCN Category to a forest reserve does not necessarily mean that the area is, or will become, effectively managed. The IUCN Categories are

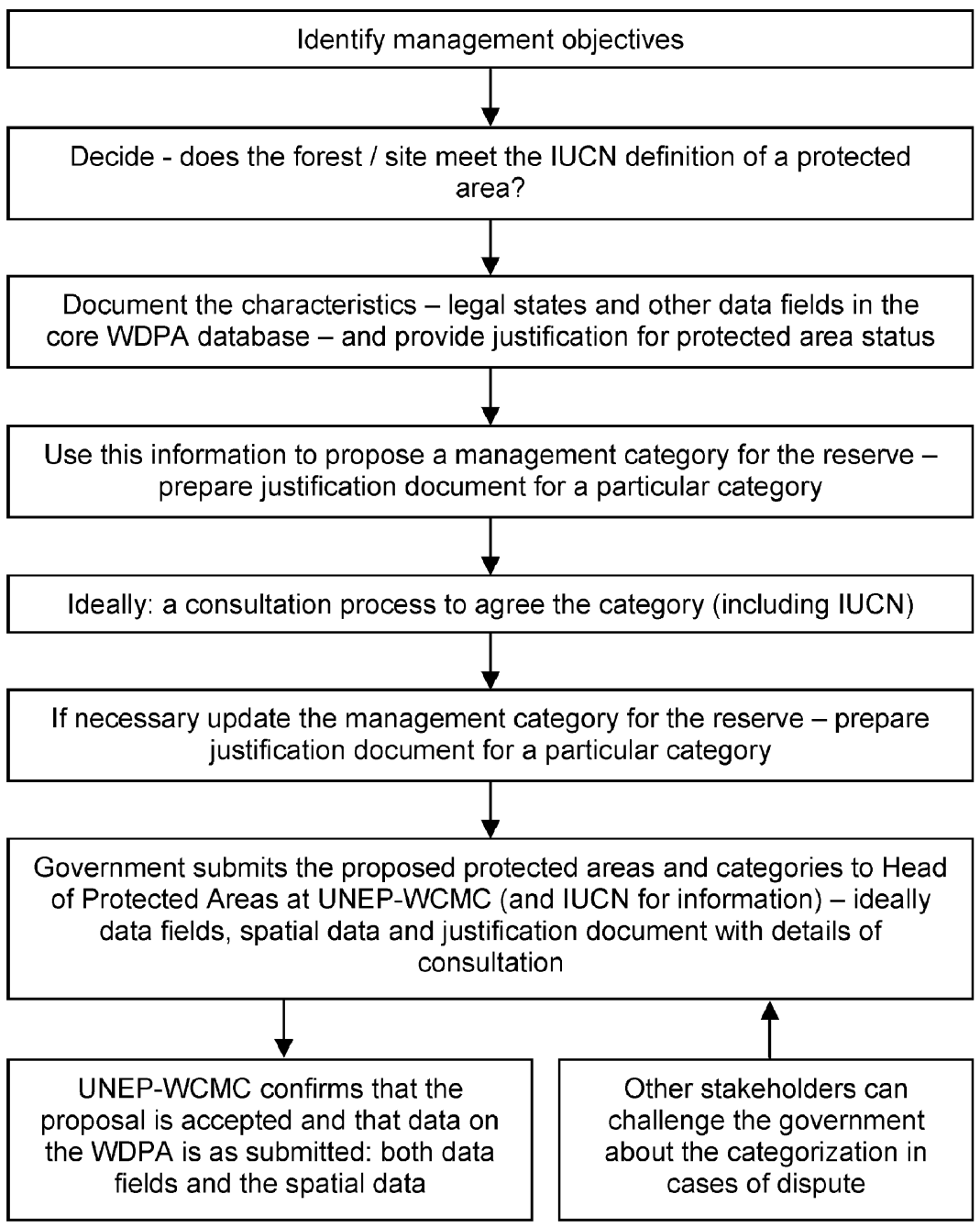

Fig. 6 Steps in the process for assigning IUCN Protected Area Categories to a given reserve. The process aims to cover various different types of reserves, but can include forest reserves (from Stolton \& Dudley, in press). 
set on management objectives and not on management effectiveness. However, tools exist to track changes in the management effectiveness of reserves (e.g. the World Bank/WWF Management Effectiveness Tracking Tool; Hockings et al., 2006; Stolton et al., 2007). The application of these tools to African forest reserves can be used to indicate the effectiveness of their current management, and whether assigning them to an IUCN Category helps improve effectiveness. Management effectiveness scores have recently been assigned to over 120 forest reserves in the Eastern Arc Mountains of Tanzania (EAMCEF, 2006).

\section{Can forest reserves help close gaps in the protected area network?}

Recent analyses have mapped the protected area gaps that remain in Africa (de Klerk et al., 2004; Fjeldså et al., 2004; Rodrigues et al., 2004a,b; Burgess et al., 2005). However, some of these gaps are largely covered on the ground by forest reserves that are not recognized as protected areas. Studies in the Eastern Arc Mountains of Tanzania and Kenya (Burgess et al., 1998; Newmark, 2002), the lowland coastal forests of eastern Africa (Burgess \& Clarke, 2000), the Kenya Highlands (Wass, 1995; Bennun \& Njoroge, 1999), the Albertine Rift Mountains of Central Africa (Plumptre et al., 2004), Uganda (Howard, 1991; Howard et al., 2000) and the Upper Guinea rainforest of West Africa (Hawthorne \& Abu-Juam, 1995; Fishpool \& Evans, 2001) have shown that networks of forest reserves either provide an important contribution to the protection of threatened, endemic or near-endemic species, or provide the only protection for such species. A more rigorous analysis of the importance of forest reserves in conserving species and hence closing protected area gaps could be completed by setting targets for the desired coverage of species (or habitats), and then running analyses using systematic conservation planning tools to assess representation and irreplaceabilty (Margules \& Pressey, 2002; Cowling et al., 2003; Pressey et al., 2003; Smith et al., 2006). Such analyses would help further refine the design of a comprehensive protected area network for Africa.

\section{Recent developments}

Some countries are making progress in assessing the contribution that their networks of forest reserves could make to a comprehensive protected area network. In the 1990s Uganda developed plans to set aside $3,190 \mathrm{~km}^{2}$ $(20 \%)$ of its forest estate as forest nature reserves (Howard et al., 2000) and is looking at how to code these reserves as IUCN categories (Uganda Forest Department Officials, pers. comms). Since 2004 the Tanzanian government has undertaken a process to assign IUCN Protected Area Management Categories to the protective catchment Forest Reserves of the Eastern Arc Mountains. This process has suggested that 93 of the 106 reserves in the Eastern Arc fit various IUCN Categories, covering c. $6,500 \mathrm{~km}^{2}$ of land. The report from this work is being published by the Forestry and Beekeeping Division in Tanzania and will be made available through EAMCEF (2006). We believe that other countries, for example Mozambique, Kenya and Senegal, are also considering the role that their networks of forest reserves play in conservation and how they could receive further recognition for this contribution to the world's protected area estate.

\section{Acknowledgements}

We thank UNEP-WCMC and the members of the WDPA consortium who have improved the WDPA and made it freely available. Without the efforts of the many people involved with the WDPA various types of analyses, such as that presented here, would not be possible. The Forestry and Beekeeping Division of the Ministry of Natural Resources and Tourism provided the data on the Forest Reserve network of Tanzania. UNEP-WCMC are thanked for allowing access to a draft of a report on the status of the protected area network in Eastern and Southern Africa. A part of that process involved a workshop in Nairobi, Kenya, attended by the following protected area professionals: Julius Arinaitwe, Damian Akankwasa, Neil Burgess, Corodius Sawe, Stuart Williams, Lakew Berhanu, Steve Nsita, Excellent Hachileka, Isila Nhantumbu, Alex Muhweezi, Evarist Nashanda, Emmanuel Gereta, Nehemiah Rotich, Estherine Lisinge, Lota Melamari, Sue Stolton, Nigel Dudley, Emmanuel Severre, Erasmus M. Tarimo, Gideon M. Amboga, Alice Kaudia, Geoffrey Howard, Laurent Ntahuga, Maurice Nyaligu, Melita Samoilys, Betty Muragori and Phillip Bubb. We also thank all the staff managing protected areas and forest reserves in Africa for their immense contribution to conserving the continent's biodiversity.

\section{References}

Bennun, L. \& Njoroge, P. (1999) Important Bird Areas in Kenya. Nature Kenya/BirdLife International, Nairobi, Kenya. Brooks, T.M., Bakarr, M.I., Boucher, T., Da Fonseca, G.A.B., Hilton-Taylor, C., Hoekstra, J.M., Moritz, T., Olivieri, S., Parrish, J., Pressey, R.L., Rodrigues, A.S.L., Sechrest, W., Stattersfield, A., Strahm, W. \& Stuart, S.N. (2004) Coverage provided by the Global Protected Area system: is it enough? BioScience, 54, 1081-1091.

Burgess, N.D. \& Clarke, G.P. (eds) (2000) The Coastal Forests of Eastern Africa. IUCN Forest Conservation Programme, Gland, Switzerland and Cambridge, UK. 
Burgess, N., D'Amico Hales, J., Underwood, E., Dinerstein, E., Olson, D., Itoua, I., Schipper, J., Ricketts, T. \& Newman, K. (2004a) Terrestrial Ecoregions of Africa and Madagascar: A Continental Assessment. Island Press, Washington, DC, USA. Burgess, N.D., Gordon, I., Salehe, J., Sumbi, P., Doggart, N., Rodgers, A. \& Clarke, P. (2004b) Coastal forests of Eastern Africa. In Hotspots Revisited: Earth's Biologically Richest and Most Endangered Terrestrial Ecoregions (eds R.A. Mittermeier, P. Robles-Gil, M. Hoffmann, J.D. Pilgrim, T.M. Brooks, C.G. Mittermeier, J.L. Lamoreux \& G.A.B. Fonseca), pp. 231-239. CEMEX, Mexico City, Mexico.

Burgess, N.D., Küper, W., Mutke, J., Westaway, S., Brown, J., Turpie, S., Meshack, C., Taplin, J., McClean, C. \& Lovett, J. (2005) Major gaps in the distribution of protected areas for threatened and narrow range Afrotropical plants. Biodiversity and Conservation, 14, 1877-1894.

Burgess, N.D., Lovett, J., Rodgers, A., Kilahama, F., Nashanda, E., Davenport, T. \& Butynski, T. (2004c) Eastern Arc Mountains and Southern Rift. In Hotspots Revisited: Earth's Biologically Richest and Most Endangered Terrestrial Ecoregions (eds R.A. Mittermeier, P. Robles-Gil, M. Hoffmann, J.D. Pilgrim, T.M. Brooks, C.G. Mittermeier, J.L. Lamoreux \& G.A.B. Fonseca), pp. 245-255. CEMEX, Mexico City, Mexico. Burgess, N.D., Nummelin, M., Fjeldså, J., Howell, K.M., Lukumbyzya, K., Mhando, L., Phillipson, P. \& Vanden Berghe, E. (eds) (1998) Biodiversity and conservation of the Eastern Arc Mountains of Tanzania and Kenya. Special Issue of the Journal of the East African Natural History Society, 87, $1-367$.

Chape, S., Blyth, S., Fish, L., Fox, P. \& Spalding, M. (2003) 2003 United Nations List of Protected Areas. UNEP-World Conservation Monitoring Centre, Cambridge, UK [also available at http://www.unep-wcmc.org/protected_areas/ UN_list/index.htm, accessed 13 February 2007].

Cowling, R.L. Pressey, R., Sims-Castley, A., le Roux, E., Baard, C.J., Burgers, G. \& Palmer, R.M. (2003) The expert or the algorithm? Comparison of priority conservation areas in the Cape Floristic Region identified by park managers and reserve selection software. Biological Conservation, 112, 147-167.

Dasmann, R.F. (1972) Towards a system for classifying natural regions of the world and their representation by National Parks and reserves. Biological Conservation, 4 , 247-255.

De Klerk, H.M., Fjeldså, J., Blyth, S. \& Burgess, N.D. (2004) Gaps in the protected area network for threatened Afrotropical birds. Biological Conservation, 117, 529-537.

EAMCEF (Eastern Arc Mountains Conservation Endowment Fund) (2006). Http://www.easternarc.or.tz [accessed 13 February 2007].

Fishpool, L. \& Evans, M.I. (eds) (2001) The Important Bird Areas of Africa and Associated Islands: Priority Sites for Conservation. BirdLife Conservation Series No. 11. Pisces Publications and BirdLife International, Newbury and Cambridge, UK.

Fjeldså, J., De Klerk, H.M., Blyth, S. \& Burgess, N.D. (2004) Where are the major gaps in the reserve network for Africa's mammals? Oryx, 38, 17-25.

Hawthorne, W.D. \& Abu-Juam, M. (1995) Forest Protection in Ghana, with Particular Reference to Vegetation and Plant Species. IUCN, Gland, Switzerland and Cambridge, UK.

Hockings, M., Stolton, S., Leverington, F., Dudley, N. \& Courrau, J. (2006) Evaluating Effectiveness - A Framework for Assessing the Management of Protected Areas. 2nd Edition. Gland, Switzerland and Cambridge, UK.
Howard, P.C. (1991) Nature Conservation in Uganda's Tropical Forests. IUCN Tropical Forest Programme, Gland, Switzerland and Cambridge, UK.

Howard, P.C., Davenport, T.R.B., Kigenyi, F.W., Viskanic, P., Baltzer, M.B., Dickinson, C.J., Lwanga, J., Matthews, R.A. \& Mupada, E. (2000) Protected area planning in the tropics: Uganda's national system of Forest Nature Reserves. Conservation Biology, 14, 858-875.

IUCN, CNPPA \& WCMC (1994) Guidelines for Applying the Protected Area Categories. IUCN, Gland, Switzerland [also available at http://www.unep-wcmc.org/protected_areas / categories/eng/index.html, accessed 13 February 2007].

Lovett, J.C. \& Wasser, S.K. (eds) (1993) Biogeography and Ecology of the Rainforests of Eastern Africa. Cambridge University Press, Cambridge, UK.

Margules, C.R. \& Pressey, R. (2000) Systematic conservation planning. Nature, 405, 243-253.

Millington, A. \& Townsend, J. (1989) Biomass Assessment. Earthscan, London, UK

Mittermeier, R.A., Robles-Gil, P., Hoffmann, M., Pilgrim, J.D., Brooks, T.M., Mittermeier, C.G., Lamoreux, J.L. \& da Fonseca, G.A.B. (eds) (2004) Hotspots Revisited: Earth's Biologically Richest and Most Endangered Terrestrial Ecoregions. CEMEX, Mexico City, Mexico.

Myers, N., Mittermeier, R.A., Mittermeier, C.G., da Fonseca, G.A.B. \& Kent, J. (2000) Biodiversity hotspots for conservation priorities. Nature, 403, 853-858.

Newmark, W.D. (2002) Conserving Biodiversity in East African Forests: A Study of the Eastern Arc Mountains. Ecological Studies, Vol. 155, Springer, Berlin, Germany.

Olson, D.M. \& Dinerstein, E. (1998) The global 200: a representation approach to conserving the Earth's most biologically valuable ecoregions. Conservation Biology, 12, 502-515.

Olson, D.M., Dinerstein, E., Wikramanayake, E.D., Burgess, N.D., Powell, G.V.N., Underwood, E.C., D'Amico, J.A., Itoua, I., Strand, H.E., Morrison, J.C., Loucks, C.J., Allnutt, T.F., Ricketts, T.H., Kura, Y., Lamoreux, J.F., Wettengel, W.W., Hedao, P. \& Kassem, K.R. (2001) Terrestrial ecoregions of the world: a new map of life on Earth. BioScience, 51, 933-938.

Plumptre, A.J., Davenport, T.R.B., Behangana, M., Kityo, R., Eliu, G., Ssegawa, P., Ewango, C. \& Kahindo, C. (2004) Albertine Rift. In Hotspots Revisited: Earth's Biologically Richest and Most Endangered Terrestrial Ecoregions (eds R.A. Mittermeier, P. Robles-Gil, M. Hoffmann, J.D. Pilgrim, T.M. Brooks, C.G. Mittermeier, J.L. Lamoreux \& G.A.B. Fonseca), pp. 255-262. CEMEX, Mexico City, Mexico.

Pressey, R.L., Cowling, R.M. \& Rouget, M. (2003) Formulating conservation targets for biodiversity pattern and process in the Cape Floristic Region, South Africa. Biological Conservation, 112, 99-127.

Rodrigues, A.S.L., Andelman, S.J., Bakarr, M.I., Boitani, L., Brooks, T.M., Cowling, R.M., Fishpool, L.D.C., da Fonseca, G.A.B., Gaston, K.J., Hoffmann, M., Long, J.S., Marquet, P.A. Pilgrim, J.D., Pressey, R.L., Schipper, J., Sechrest, W., Stuart, S.N., Underhill, L.G., Waller, R.W., Watts, M.E.J. \& Yan, X. (2004a) Effectiveness of the global protected area network in representing species diversity. Nature, 428, 640-643.

Rodrigues, A.S.L., Akçakaya, H.R., Andelman, S.J., Bakarr, M.I., Boitani, L., Brooks, T.M., Chanson, J.S., Fishpool, L.D.C., da Fonseca, G.A.B., Gaston, K.J., Hoffmann, M., Marquet, P.A., Pilgrim, J.D., Pressey, R.L., Schipper, J., Sechrest, W., Stuart, S.N., Underhill, L.G., Waller, R.W., Watts, M.E.J. \& Yan, X. (2004b) Global gap analysis: priority regions for expanding the global Protected-Area network. BioScience, 54, 1092-1100. 
Smith, R.J., Goodman, P.S. \& Matthew, W.S. (2006) Systematic conservation planning: a review of perceived limitations and an illustration of the benefits, using a case study from Maputaland, South Africa. Oryx, 40, 400-410.

Stattersfield, A.J., Crosby, M.J., Long, A.J. \& Wege, D.C. (1998) Endemic Bird Areas of the World. Priorities for Biodiversity Conservation. BirdLife Conservation Series No. 7. BirdLife International, Cambridge, UK.

Stolton, S. \& Dudley, N. (eds) (in press) Protected Areas in Eastern and Southern Africa: Reporting Protected Areas and Applying the IUCN Categories. UNEP-WCMC, Cambridge, UK.

Stolton, S., Hockings, M., Dudley, N., MacKinnon, K., Whitten, T. \& Leverington, F. (2007) Management Effectiveness Tracking Tool: Reporting Progress at Protected Area Sites. 2nd edition. WWF, Gland, Switzerland.

Wass, P. (ed.) (1995) Kenya's Indigenous Forests: Status, Management and Conservation. IUCN Forest Conservation Programme, Gland, Switzerland and Cambridge, UK.

WDPA Consortium (2005) 2005 World Database on Protected Areas. Http://www.unep-wcmc.org/wdpa [accessed 14 February 2007].

\section{Biographical sketches}

Neil Burgess is a conservationist specializing in Africa. His research focuses on African biogeography, conservation priorities, protected areas (especially forest reserves), and the high biodiversity forests of eastern Africa. He also works in practical conservation in the field.

Colby Loucks is a conservation biologist with WWF-US's Conservation Science Program. His work focuses on using spatial analyses to assist field programmes and inform decision-makers.

Sue Stolton is a member of IUCN's World Commission on Protected Areas and the author of several publications on the management effectiveness of protected areas. She also works closely with protected area managers in Africa.

Nigel Dudley is an ecologist and writer. His work focuses on issues relating to protected areas, forest quality, and landscape approaches to conservation in over 50 countries. 